\title{
LMP1 Immunohistochemistry in Non-Hodgkin's Lymphoma of Sudanese Cases
}

\author{
Amal Ismail1*, Ihsan Osman², Nazik Elmalaika Husain ${ }^{3}$ \\ ${ }^{1}$ Medical Doctorate Student, Pathology Department, Khartoum University, Khartoum, Sudan \\ ${ }^{2}$ Pathology Department, Alzaiem Alazhari University, Khartoum, Sudan \\ ${ }^{3}$ Pathology Department, Omdurman Islamic University, Omdurman, Sudan \\ Email: *amal.zumrawy2012@gmail.com, Ihsanosman@hotmail.com, nazikhusain@gmail.com
}

Received 16 January 2016; accepted 15 April 2016; published 18 April 2016

Copyright (C) 2016 by authors and Scientific Research Publishing Inc.

This work is licensed under the Creative Commons Attribution International License (CC BY). http://creativecommons.org/licenses/by/4.0/

(c) (i) Open Access

\section{Abstract}

Back ground: Non-Hodgkin's lymphoma (NHL) with its different subtypes is strongly related to Epstein Bar virus (EBV) infection mainly Burkitt's lymphoma in Africa. Studies proved the role of EBV in tumor-genesis and linked it to prognosis and therapy of patients. Objectives: To determine the frequency of EBV in non-Hodgkin lymphomas using EBV latent membrane protein 1 (EBVLMP1) immunohistochemical stain. Methods: This cross-sectional study was conducted at radio-isotope centre of Khartoum (2012-2014). A total of 75 cases of non-Hodgkin lymphoma paraffin embedded sections were stained for EBV LMP1 antibody. Data were analyzed by SPSS 16 and statistical cross linking of the results of immune staining with other data was done. Results: Out of 75 patients of non Hodgkin's lymphoma (74.7\%) were males. EBV-LMP1 Immune-staining was positive in $(17.3 \%)$ with predominance of Burkitt's lymphoma (33.3\%), followed by diffuse large B cell lymphoma (17.9\%). Conclusion: Burkitt's lymphoma expressed the highest percentage of non-Hodgkin's lymphoma positive cases $(46.2 \%)$ out of the total $(17.3 \%)$ positive cases. Different methods need to be used in studying Burkitt's lymphoma expression of EBV and its effects on the treatment and prognosis of cases.

\section{Keywords}

Epstein Bar Virus, Latent Membrane Protein 1 LMP1, Non-Hodgkin's Lymphoma, Immunohistochemistry

\footnotetext{
${ }^{*}$ Corresponding author.
}

How to cite this paper: Ismail, A., Osman, I. and Husain, N.E. (2016) LMP1 Immunohistochemistry in Non-Hodgkin's Lymphoma of Sudanese Cases. Open Journal of Pathology, 6, 79-87. 


\section{Introduction}

Epstein Bar virus (EBV) is a member of the G herpes virus family with demonstrated B-cell lympho-tropism. Many studies relate it to carcinogenesis in lymphoma mainly Burkitt's lymphoma cell and HIV related lymphoma. Furthermore, it has been associated with epithelial malignancies arising in the gastric region, the breast and nasopharyngeal carcinoma in immune-compromised individuals [1].

EBV approximately infects most of the adult population in the world. It encodes series of products interacting with or similar to many of antiapoptotic molecules, cytokines, and signal transducers, so enhancing EBV infection, defected apoptosis and malignant transformation [2]-[5].

Different molecules are involved in EBV latent infection, including EBV-encoded nuclear antigens (EBNAs); EBNA leader protein (EBNA-LP); latent membrane protein (LMP) 1, LMP2A, and LMP2B; and EBV encoded RNAs (EBERs) EBER1 and EBER2. Among these, LMP1 is essential for EBV-mediated oncogenic effects. The C-terminal region ofLMP1 protein can regulate different cellular signaling pathways such as TNF receptor, $\mathrm{NF}-\kappa \mathrm{B}$ and JAK/STAT in order to regulate proliferation, immortalization, and invasion process [1] [6] [7].

Non-Hodgkin lymphomas (NHL) represent a heterogeneous group of lymphoid malignancies with distinct molecular pathogenesis leading to activation of proto-oncogenes (e.g. BCL-1, BCL-2, BCL-6, c-MYC) or disruption of tumor suppressor genes (e.g. p. 53). These lesions combine into multiple molecular pathways [8]. The number of non-Hodgkin's lymphoma (NHL) cases has increased rapidly through the last few years. There were an estimated 356000 new cases of NHL and 192000 deaths from NHL worldwide in 2008. The disease accounts for $\sim 5.1 \%$ of all cancer cases and $2.7 \%$ of all cancer deaths. Areas with highest incidence of NHL include North America, Europe, Oceania, as well as several African countries [9]. At the current time, few data are given about the reasons for this increase or about exactly what causes non-Hodgkin's lymphoma; we only know some of the risk factors of non-Hodgkin's lymphoma. Studying patterns of cancer in the population has identified certain risk factors which are more common in people who get non-Hodgkin's lymphoma than in those who do not. However, most people with these risk factors do not get non-Hodgkin's lymphoma, and vice versa. Getting non-Hodgkin's lymphoma increases with age and is more common in men than in women. It is more common among people with immunodeficiency and those infected with Human T-lymphotropic virus type I (HTLV-1), helicobacter pylori and HIV. People exposed to certain chemicals, such as fertilizers pesticides, or solvents are more prone to develop non-Hodgkin's lymphoma [10].

Burkitt's lymphoma is a common type of non Hodgkin's lymphoma in Sudanese population specially the pediatric group either in the endemic form in the jaw or as sporadic cases. It's classification as high grade lymphoma and its impact on young age group are deserving more digging in etiological factors and more searching for causes. Different studies are suggesting EBV not only as etiological factor but also as prognostic and therapy affecting factor [2] [6] [11] [12]. Diagnosis of cases of non Hodgkin's lymphoma needs to be screened and reclassified according to its association with EBV. In this study we tried to find out the frequency of EBV in non Hodgkin's lymphoma subclasses depending on the positivity of LMP immunohistochemical staining and relate it to age, gender and site.

\section{Methods}

This cross sectional and descriptive, hospital-based study was conducted at Radioisotope Centre of Khartoum (RICK). All cases of non-Hodgkin's lymphoma diagnosed at histopathology and immunohistochemistry department in RICK within the years (2012-2014) were reviewed. Poorly fixed or inadequately processed tissue blocks were excluded. Seventy five cases of non Hodgkin's lymphoma were included in this study. Four histological sections were obtained from each block one in ordinary frosted slide for (hematoxylin and eosin stain-H/E-stain) and three in positively charged slides (for immunohistochemical stain. Briefly the first section wasde-paraffinized and dehydrated. Mayer's hematoxylin applied for 15 minutes then washed in running tap water for 20 minutes, counter stained with eosin for 2 minutes, dehydrated in $95 \%$ absolute alcohol until excess eosin was removed then cleared in xyleme and checked under microscope the other three sections were incubated overnight in a hot air oven (LABTECH-INDIA) at $60^{\circ} \mathrm{C}$ c temperature. Properly fixed samples as much as possible were selected and satisfactory overnight incubation not to lose the tissue in immune staining was guaranteed. Antigen retrieval was done by (Dako-USA) citrate buffer in PH 9 in 95c for 30 minutes, endogenous peroxidase activity was blocked with $3 \%$ hydrogen peroxidase and methanol (Sigma Aldrich) for 10 minutes, Then slides were incubated with 100 - $200 \mu$ of primary antibody for 30 minutes at room temperature followed 
by adding antibody enhancer for 10 minutes. The primary antibody for EBV LMP1 (Dako-USA) was used. The negative control slides were incubated with Bovine serum albumin instead of the primary antibody. After washing with Phosphate buffer saline for 3 minutes, binding of antibody was detected by incubation for 20 minutes with dextran labeled polymer Dako envision TM flex kit (secondary antibody). Diaminobenzidine tetra hydrochloride DAB chromogen (prepared by adding 1drop in $1 \mathrm{ml}$ ) was added for up to 10 minutes. Counter staining with hematoxylin was done and lastly slides were prepared. H/E slides were revised in order to select the tissue representative for tumor cells in a trial to avoid non specific staining and necrotic areas and compared with immunohistochemistry slides. Instructions of manufacturer of the antibody were followed and detection system was freshly prepared to avoid contamination problems. Interpretation of positive slides with the supervisor (heamato-pathologist) was accomplished by light microscopy (Olymbus BX51TF Tokyo, Japan). Positive results are considered if there is cytoplasmic staining. Scoring was done on the basis of the percentage of positive tumor cells and the relative immune staining intensity. Sections grading system was used to score the number of positive tumor cells: 0 , none seen in the section; 1 , presence of positive cells even rare but not exceeding $25 \%$; 2, $26 \%$ to $50 \%$ positive cells; $3,51 \%$ to $75 \%$; and $4,76 \%$ to $100 \%$. Immune-staining intensity was rated as follows: 0 , none; 1 , weak; 2 , moderate; and 3 , intense. When the staining intensity was heterogeneous, each component of the tumor was scored independently and the results were averaged. For example, when a specimen contained $50 \%$ of the tumor cells with moderate intensity $(2 \times 2=4), 25 \%$ of tumor cells with intense immune staining $(1 \times 3=3)$, and $25 \%$ of cells with weak intensity $(1 \times 1=1)$, the score were $4+3+1=8$. The maximum possible score was twelve [13]. False positive interpretation especially of the edge artifacts was avoided. Photographing of positive samples with different staining intensity lastly was done using Olympus DP 70 controller software and was processed using Olympus DP manager software. Data acquisition sheet filled with data and results of LMP1 staining. Data were analyzed electronically using computer program (SPSS version 17). $\mathrm{T}$ test and Chi-Square tests were calculated to compare the association.

The study was approved by the ethical committee of Medical Doctorate of Pathology University of Khartoum. Permission for conduction of the study was achieved from RICK director and patient's written consent was obtained.

\section{Results}

The included 75 cases of Non Hodgkin lymphoma were 56 males and 19 females. The minimum age was three years and the maximum age was ninety-five with mode of four years, 49 years was the median and the standard deviation was 24, 5. Cases were stained for EBV LMP1 immunostain and 17\% cases of non Hodgkin lymphoma were positive. About (23.1\%) of patients expressed positive results below the age of 16 years while (23.8\%) of the twenty three of the range group (46 - 60) showed positive results (Figure 1). There was no significant difference between age groups with positive and negative LMP1 stained cases.

Regarding the gender distribution from the Fifty six male patients (84.6) \% expressed positive results versus (15.4\%) of the nineteen female patient's (Figure 2).

No statistical difference between male and female positive cases.

Site of the lymphoma: There is nodal distribution of sixty seven (89.3\%) of the cases in different lymph node groups (Table 1). Extra nodal distribution of non Hodgkin lymphoma cases were as follow: Two cases (2.6\%) from gastric tissue, eyelid, thyroid, ovary, oro-pharynx, testis and bowel. The total number of extra nodal cases is eight $(10.7 \%)$.

Thirty three (44\%) of the cases were diffuse large B cell lymphoma while eighteen (24\%) of Burkett's lymphoma (Figure 3).

LMP1 stain result: Thirteen (17\%) cases of non Hodgkin lymphoma were positive with three (23.1\%) exhibiting weak positivity and six (46.2\%) intermediate positivity and only four 30.8\% showed strong positivity (Figure 4 and Figure 5).

\section{Discussion}

EBV role in tumor-genesis of non Hodgkin's lymphoma is becoming more obvious, while still the management remains unsatisfactory. Exploration of antiviral drugs and therapies based on specific monoclonal antibodies has encouraging results [14] [15]. Immunohistochemistry has developed as an efficient tool to demonstrate the presence of EBV by detecting latent viral antigens. In this study non Hodgkin's lymphoma cases showed 17.3\% 


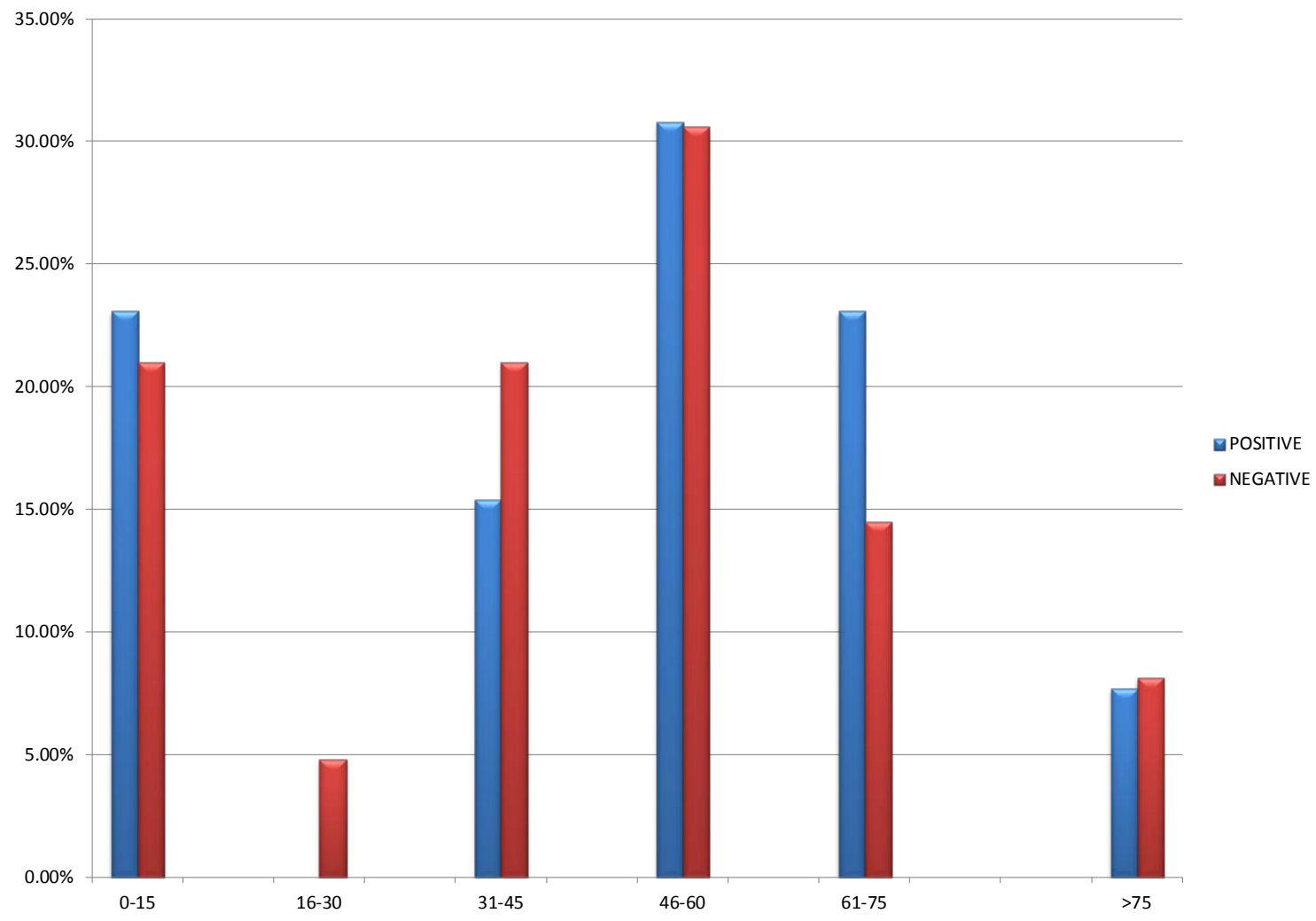

Figure 1. Age groups distribution with LMP1 results among the studied patients.

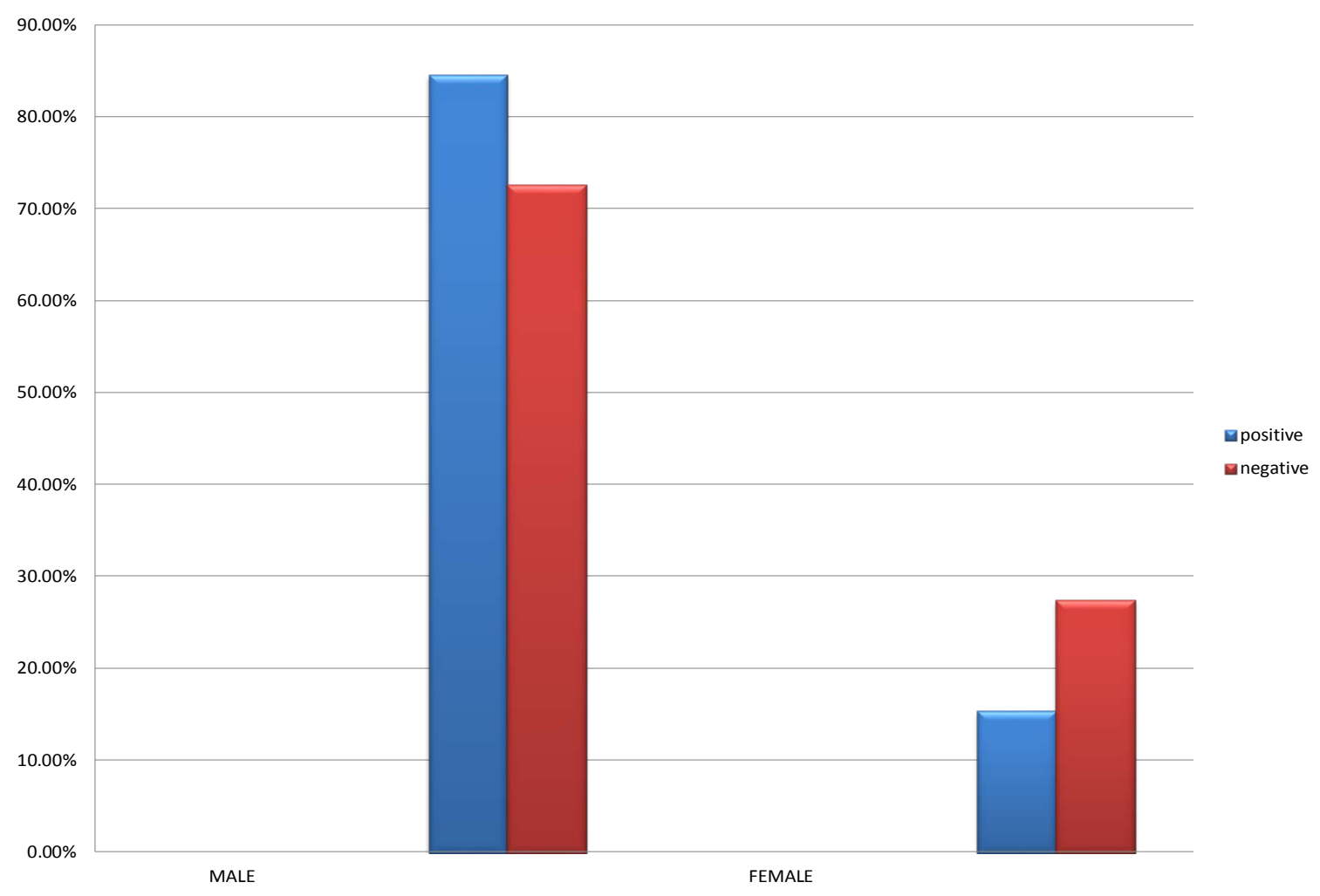

Figure 2. Distribution of the positive LMP1 according to gender among the studied group. 
Table 1. Nodal distribution and LMP1 results among the studied group.

\begin{tabular}{|c|c|c|c|c|}
\hline & & \multicolumn{2}{|c|}{ LMP1 RESULT } & \multirow{2}{*}{ TOTAL } \\
\hline & & POSITIVE & NEGATIVE & \\
\hline \multirow{2}{*}{ MESENTRIC } & Count & 5 & 13 & 18 \\
\hline & \% within LMP1 RESULT & $45.5 \%$ & $23.2 \%$ & $26.9 \%$ \\
\hline \multirow{2}{*}{ AXIILLARY } & Count & 1 & 15 & 16 \\
\hline & \% within LMP1 RESULT & $9.1 \%$ & $26.8 \%$ & $23.9 \%$ \\
\hline \multirow{2}{*}{ CERVICAL } & Count & 5 & 21 & 26 \\
\hline & \% within LMP1 RESULT & $45.5 \%$ & $37.8 \%$ & $26.9 \%$ \\
\hline \multirow{2}{*}{ INGUINAL } & Count & 0 & 5 & 5 \\
\hline & \% within LMP1 RESULT & $.0 \%$ & $10.7 \%$ & $9.0 \%$ \\
\hline \multirow{2}{*}{ PARAAORTIC } & Count & 0 & 2 & 2 \\
\hline & \% within LMP1 RESULT & $.0 \%$ & $3.6 \%$ & 3.0 \\
\hline \multirow{2}{*}{ TOTAL } & Count & 11 & 56 & 67 \\
\hline & \% within LMP1 RESULT & $100.0 \%$ & $100.0 \%$ & $100.0 \%$ \\
\hline
\end{tabular}

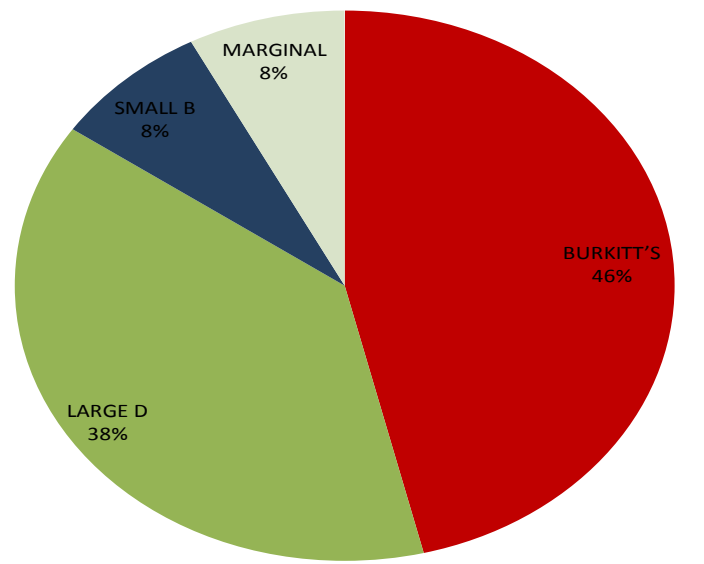

Figure 3. Non-Hodgkin's lymphoma subtypes among the studied group.

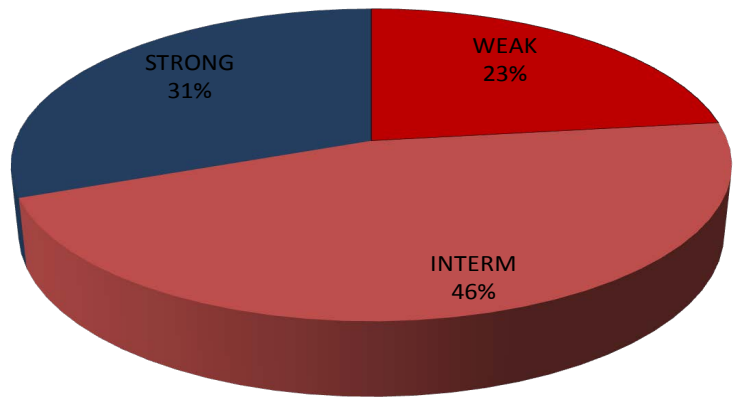

Figure 4. LMP1 intensity of staining in the studied group. 


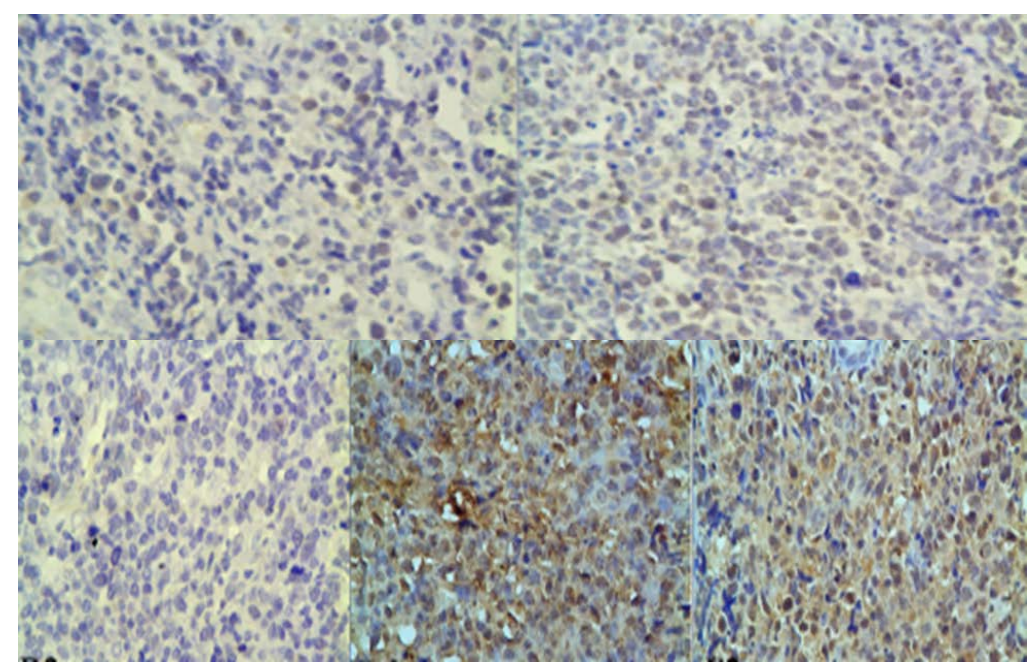

Figure 5. Different staining among the studied group.

positivity of latent membrane antigen antibodies compared with $30 \%$ and $12.7 \%$ expression of positivity of NHL cases in other similar studies [16] [17]. Other studies were done only on B cell type of lymphoma mostly Burkitt’s lymphoma. Gonin J. and Larousserie F expressed positivity in 34.7\% [17], while Oyama [18], Morales [19] and Park studies [20] showed positivity ranging from 9\% to $15 \%$.

EBV positive NHL can occur in different age groups. In this study it was found to be more common in age group 46 - 60 years (30.7\%) followed by the group of ages from 31 - 46 years forming $20 \%$ of the total with a mean age (48.7). The low mean in this study is resulting from more pediatric group range (1 - 15 years) (21.3\%) with 4 years old as the more repeated mode. The youngest patient with Burkitt's lymphomain this study is 3 years old. Most of the patients were in the $6^{\text {th }}$ decade followed by the $1^{\text {st }}$ decade. LMP1 positivity was seen more among the age group (46 - 60) years (30.8\%). This may be related to immunity deterioration with increasing age [21]. No significant difference among age groups expressing positivity in comparison with significant variation in another study done by Park and his colleagues [20].

It was found that NHL was more common among males (74.7\%). expressing (84.6\%) of the positive LMP1 cases in the current study. This is in concordance to Tumwine LK and his colleagues study with similar male cases predominance but with majority of female positive cases comprising 86.5\% [22].

LMP1 positivity among the different morphological subtypes showed that nearly half (46.2\%) of the positive cases were Burkitt's lymphoma this supports the theory of latency type transformation and the relationship between Burkitt's lymphoma and EBV infection [22]. It was followed by Diffuse large B cell lymphoma (38.5\%) similar to the results of Lynnette K Tumwine and his group study in Uganda [22] and this may be due to geographical distribution of Burkitt lymphoma in African malaria endemic area. It also agrees with the study of Osman. IM concluding that sporadic Burkitt's lymphoma of the gastrointestinal tract is the predominant pediatric lymphoma while diffuse large B cell lymphoma is the commonest in adult [23].

Regarding marginal zone lymphoma a study of 17 cases of inflammatory bowel disease (IBD) associated colorectal cancer and 9 of NHL were considered for EBV expression of latent membrane proteins and results suggested that EBV to be involved in the pathogenesis of proportion of cases of marginal zone lymphoma [22] and this may explain our positive case result.

No studies found in the literature on small cell lymphoma and mantle cell lymphoma relating it with EBV latent proteins expression but theory of malignancy transformation is not proofed.

A study on T cell lymphoma represented by Yuan Mao and colleagues using LMP1 on 16 cases yielded (56.25\%) positivity [24]. In the current study T cell lymphoma cases were few and no case showed positivity to be compared with the B cell lymphoma positivity.

In this study grading system was applied on positive results. It is found that $77 \%$ were of intermediate and strong positivity. Some studies relate the concentration of LMP1 to the prognosis of patients and potentiality of metastasis [25]. Further study is needed to follow up these patients and relate grade of LMP1 with outcome and risk of metastasis. 


\section{Conclusions}

LMP1 positive expression was in $17.3 \%$ non Hodgkin's lymphoma cases. The majority were within the age group (46 - 60 years) and pediatric age group below fifteen years old with none statistically significant male predominance. About one third of the LMP1 positive cases were sporadic Burkitt's lymphoma with the commonest site in mesenteric lymph nodes. Only two cases of endemic Burkitt's lymphoma were identified, one of them was LMP1 positive. Diffuse large B cell lymphoma following Burkitt's lymphoma in frequency of positive cases, with small B cell and marginal zone lymphoma coming next. Most of the findings of this study correlate with the published English literature.

It is recommended that similar study to be carried out in larger sample size and combined with additional methods like PCR and ERB1 in situ hybridization or EBNA1 immune stain to detect EBV antigen and make interpretation comparable with the co-method used

\section{References}

[1] Crawford, D.H. (2001) Biology and Disease Associations of Epstein-Barr Virus. Philosophical Transactions of the Royal Society B: Biological Science, 356, 461-473. http://dx.doi.org/10.1098/rstb.2000.0783

[2] Kieff, E. and Rickinson, A.B. (2001) In: Knipe, D.M., Howley, P.M. and Griffin, D.E., Eds., Fields Virology, Lippincott Williams \& Wilkins, Philadelphia, 2511-2573.

[3] Wilson, J.B., Weinberg, W., Johnson, R., Yuspa, S. and Levine, A.J. (1990) Expression of the BNLF-1 Oncogene of Epstein-Barr Virus in the Skin of Transgenic Miceinduces Hyperplasia and Aberrant Expression of Keratin 6. Cell, 61, 1315-1327. http://dx.doi.org/10.1016/0092-8674(90)90695-B

[4] Kulwichit, W., Edwards, R.H., Davenport, E.M., Baskar, J.F., Godfrey, V. and Raab-Traub, N. (1998) Expression of the Epstein-Barr Virus Latent Membrane Protein 1 Induces B Cell Lymphoma in Transgenic Mice. Proceedings of the National Academy of Sciences of the United States of America, 95, 11963-11968. http://dx.doi.org/10.1073/pnas.95.20.11963

[5] Stevenson, D., Charalambous, C. and Wilson, J.B. (2005) Epstein-Barr Virus Latent Membrane Protein 1 (CAO) Up-Regulates VEGF and TGFa Concomitant with Hyperlasia, with Subsequent Up-Regulation of p16 and MMP9. Cancer Research, 65, 8826-8835. http://dx.doi.org/10.1158/0008-5472.CAN-05-0591

[6] Young, L.S. and Murray, P.G. (2003) Epstein-Barr Virus and Oncogenesis: From Latent Genes to Tumours. Oncogene, 22, 5108-5121. http://dx.doi.org/10.1038/sj.onc.1206556

[7] Shair, K.H., Bendt, K.M., Edwards, R.H., Bedford, E.C., Nielsen, J.N. and Raab-Traub, N. (2007) EBV Latent Membrane Protein 1 Activates Akt, NFkappaB, and Stat3 in B cell Lymphomas. PLOS Pathogens, 3, e166. http://dx.doi.org/10.1371/journal.ppat.0030166

[8] Ferlay, J., Shin, H.R. and Bray, F. (2008) Estimates of Worldwide Burden of Cancer in 2008: GLOBOCAN 2008. International Journal of Cancer, 127, 2893-2917. http://dx.doi.org/10.1002/ijc.25516

[9] Gaidano, G., Pastore, C. and Volpe, G. (1995) Molecular Pathogenesis of Non-Hodgkin Lymphoma: A Clinical Perspective. Haematologica, 80, 454-472.

[10] Grulich, A.E., Vajdic, C.M. and Cozen, W. (2007) Altered Immunity as a Risk Factor for Non-Hodgkin Lymphoma. Cancer Epidemiology, Biomarkers \& Prevention, 16, 405-408.

[11] Vrzalikova, K., Vockerodt, M., Leonard, S., Bell, A., Wei, W., Schrader, A., Wright, K.L., Kube, D., Rowe, M., Woodman, C.B. and Murray, P.G. (2011) Down-Regulation of BLIMP1 $\alpha$ by the EBV Oncogene, LMP-1, Disrupts the Plasma Cell Differentiation Program and Prevents Viral Replication in B Cells: Implications for the Pathogenesis of EBV-Associated B-Cell Lymphomas. Blood, 117, 5907-5917. http://dx.doi.org/10.1182/blood-2010-09-307710

[12] Mei, Y.P., Zhou, J.M., Wang, Y., Huang, H., et al. (2007) Silencing of LMP1 Induces Cell Cycle Arrest and Enhances Chemosensitivity through Inhibition of AKT Signaling Pathway in EBV Positive Nasopharyngeal Carcinoma Cells. Cell Cycle, 6, 1379-1385. http://dx.doi.org/10.4161/cc.6.11.4274

[13] Khabir, A., Karray, H., Rodriguez, S., Rosé, M., Daoud, J., Frikha, M., Boudawara, T., Middeldorp, J., Jlidi, R. and Busson, P. (2005) EBV Latent Membrane Protein 1 Abundance Correlates with Patient Age but Not with Metastatic Behavior in North African Nasopharyngeal Carcinomas. Virology Journal, 2, 39. http://dx.doi.org/10.1186/1743-422X-2-39

[14] Nourse, J.P., Crooks, P., Keane, C., Nguyen-Van, D., Mujaj, S., Ross, N., Jones, K., Vari, F., Han, E., Trappe, R., Fink, S. and Gandhi, M.K. (2012) Expression Profiling of Epstein-Barr Virus-Encoded microRNAs from Paraffin-Embedded Formalin-Fixed Primary Epstein-Barr Virus-Positive B-Cell Lymphoma Samples. Journal of Virological Methods, 184, 46-54. http://dx.doi.org/10.1016/j.jviromet.2012.05.005 
[15] Omoti, C.E., Nwannadi, A.I., Obieche, J.C. and Olu-Eddo, A.N. (2012) The Epidemiological Features of Lymphoid Malignancies in Benin City, Nigeria: A 15 Years Study. The Pan African Medical Journal, 11, 10.

[16] Ishtiaq, S., Hassan, U., Mushtaq, S. and Akhtar, N. (2013) Determination of Frequency of Epstein-Barr Virus in Non-Hodgkin Lymphomas Using EBV Latent Membrane Protein 1 (EBV-LMP1) Immunohistochemical Staining. Asian Pacific Journal of Cancer Prevention, 14, 3963-3967. http://dx.doi.org/10.7314/APJCP.2013.14.6.3963

[17] Gonin, J., Larousserie, F., Bastard, C., Picquenot, J.-M., Couturier, J., Radford-Weiss, I., Dietrich, C., et al. (2011) Epstein-Barr Virus-Induced Gene 3 (EBI3): A Novel Diagnosis Marker in Burkitt Lymphoma and Diffuse Large B-Cell Lymphoma. PLoS ONE, 6, e24617. http://dx.doi.org/10.1371/journal.pone.0024617

[18] Oyama, T., Yamamoto, K., Asano, N., Oshiro, A., Suzuki, R., Kagami, Y., Morishima, Y., Takeuchi, K., Izumo, T., Mori, S., Ohshima, K., Suzumiya, J., Nakamura, N., et al. (2007) Age-Related EBV Associated B-Cell Lymphoproliferative Disorders Constitute a Distinct Clinicopathologic Group: A Study of 96 Patients. Clinical Cancer Research, 13, 5124-5132. http://dx.doi.org/10.1158/1078-0432.CCR-06-2823

[19] Morales, D., Beltran, B., De Mendoza, F.H., Riva, L., Yabar, A., Quiñones, P., Butera, J.N. and Castillo, J. (2010) Epstein-Barr Virus as a Prognostic Factor in de Novo Nodal Diffuse Large B-Cell Lymphoma. Leukemia \& Lymphoma, 51, 66-72. http://dx.doi.org/10.3109/10428190903308015

[20] Park, S., Lee, J., Ko, Y.H., Han, A., Jun, H.J., Lee, S.C., Hwang, I.G., Park, Y.H., Ahn, J.S., Jung, C.W., Kim, K., Ahn, Y.C., Kang, W.K., Park, K. and Kim, W.S. (2007) The Impact of Epstein-Barr Virus Status on Clinical Outcome in Diffuse Large B-Cell Lymphoma. Blood, 110, 972-978. http://dx.doi.org/10.1182/blood-2007-01-067769

[21] Adam, P., Bonzheim, I., Fend, F. and Quintanilla-Martínez, L. (2011) Epstein-Barr Virus-Positive Diffuse Large B-Cell Lymphomas of the Elderly. Advances in Anatomic Pathology, 18, 349-355. http://dx.doi.org/10.1097/PAP.0b013e318229bf08

[22] Tumwine, L.K., Orem, J., Kerchan, P., Byarugaba, W. and Pileri, S.A. (2010) EBV, HHV8 and HIV in B Cell Non Hodgkin Lymphoma in Kampala, Uganda. Infectious Agents and Cancer, 5, 12. http://dx.doi.org/10.1186/1750-9378-5-12

[23] Osman, I.M., Mohamadani, A. and Mohamed Kheir, S. (2014) Non-Hodgkin Lymphoma in Sudanese Children. Sudan Journal of Medical Sciences, 9, 31-38.

[24] Mao, Y., Zhang, D.-W., Zhu, H., Lin, H., Xiong, L., Cao, Q., Liu, Y., Li, Q.-D., Xu, J.-R., Xu, L.-F. and Chen, R.-J. (2012) LMP1 and LMP2A Are Potential Prognostic Markers of Extranodal NK/T-Cell Lymphoma, Nasal Type (ENKTL). Diagnostic Pathology, 7, 178. http://dx.doi.org/10.1186/1746-1596-7-178

[25] Horikawa, T., Yoshizaki, T., Sheen, T.-S., Lee, S.-Y. and Furukawa, M. (2000) Association of Latent Membrane Protein 1 and Matrix Metalloproteinase 9 with Metastasis in Nasopharyngeal Carcinoma. Cancer, 89, 715-723. http://dx.doi.org/10.1002/1097-0142(20000815)89:4<715::aid-cncr1>3.0.c0;2-9 


\section{Abbreviations}

$\begin{array}{ll}\text { BCL2 } & \text { B cell lymphoma } 2 \\ \text { EBERs } & \text { EBV encoded RNAs } \\ \text { EBNA-LP } & \text { EBNA leader protein } \\ \text { EBNAs } & \text { Encoded nuclear antigens } \\ \text { EBV } & \text { Epstein Bar virus } \\ \text { HTLV-1 } & \text { Human T-lymphotropic virus type I } \\ \text { IBD } & \text { Inflammatory bowel disease } \\ \text { JAK/STAT } & \text { Janus kinase and signal transducer and activator of transcription } \\ \text { LMP } & \text { latent membrane protein } \\ \text { MYC } & \text { Myelocytomatosis oncogen homolog } \\ \text { NF- } \text { B } & \text { nuclear factor kappa-light chain-enhancer of activated B cells } \\ \text { PCR } & \text { Polymerase chain reaction } \\ \text { RICK } & \text { Radioisotope Centre of Khartoum } \\ \text { SERS } & \text { surface enhanced Raman scatter } \\ \text { TNF } & \text { Tumor necrosis factor }\end{array}$

